\title{
Sebastian Kwiecień
}

Katolicki Uniwersytet Lubelski Jana Pawła II

\section{POLSKIE PRAWO PRZEMYSŁOWE 1927-1939}

\section{Polskie PRAWo PRZEMYSŁOWE}

Wzajemne stosunki państwa i przemysłu uległy istotnym zmianom na początku wieku XX. Nastąiła wówczas koncentracja środków produkcji i kapitału w jednym podmiocie gospodarczym. Tak głębokie przemiany gospodarcze znalazły swoje odzwierciedlenie w ustawodawstwie przemysłowym. Państwo porzuciło stanowisko pozornej i formalnej obojętności gospodarczej i czynnie weszło w sferę działalności przemysłowej, rozpoczynając w polityce gospodarczej państwa okres interwencjonizmu. Powstały wtedy wielkie przedsiębiorstwa, uzyskujące coraz większy wpływ na ustawodawstwo, poprzez działania polegające na uzyskiwaniu prawnej ochrony zdobytej pozycji. Ochrona ta przejawiała się przez wprowadzenie obowiązku uzyskiwania koncesji na prowadzenie danej działalności ${ }^{1}$. Na okres powyższy przypadła pierwsza spójna polska kodyfikacja prawa przemysłowego (swoista konstytucja prowadzenia przemysłu), tj. rozporządzenie Prezydenta Rzeczypospolitej z 7 czerwca 1927 roku o prawie przemysłowem ${ }^{2}$, wzorowane w głównej mierze na austriackiej i niemieckiej ordynacji przemysłowej.

1 J. Starościak, Polskie prawo administracyjne, Warszawa 1958, s. 6. Por. J. BRAun, Korporacyjna budowa przemystu i handlu, Lublin 1939, s. 6-7

${ }^{2}$ Dz.U. Nr 53, poz. 468. 
Do czasu wejścia w życie rozporządzenia o prawie przemysłowym na terenie odrodzonego państwa polskiego obowiązywały przepisy dzielnicowe, które w sposób odmienny regulowały między innymi sposób nabywania uprawnień przemysłowych, zatwierdzania projektów urządzenia zakładów przemysłowych czy praw i obowiązków związanych $\mathrm{z}$ wykonywaniem przemysłu ${ }^{3}$. Istniała zatem pilna potrzeba ustalenia jednolitych norm zasadniczych, które odpowiadałyby potrzebie czasów i czyniły zadość postanowieniom Konstytucji marcowej, tj. wyrażonej w niej zasadzie wolności wyboru zajęcia i zarobkowania ${ }^{4}$.

Prace nad ustawodawstwem przemysłowym zapoczattkowała rezolucja Sejmu Ustawodawczego z dnia 10 lipca 1919 roku, w której wezwano rząd do szybkiego opracowania i przedłożenia projektu ustawy przemysłowej. Uprzedzając powyższą uchwalę, Ministerstwo Przemysłu i Handlu rozpoczęło prace nad projektem ustawy przemysłowej. Z uwagi na działania wojenne prowadzone na terytorium Polski, prace zostały zawieszone do roku 1921, kiedy to opracowano szczegółowy program pracy nad ustawą. Przygotowany projekt przez ministerstwo $\mathrm{w}$ pierwszej kolejności skonsultowano $\mathrm{z}$ pozostałymi ministrami, a następnie przekazano go do obszernej ankiety pisemnej. W grudniu 1921 roku rozesłało projekt ustawy m.in. do urzędów wojewódzkich, izb handlowych, przemysłowych oraz rzemieślniczych ${ }^{5}$.

Wyniki ankiety wykazały wiele rozbieżności co do wizji kodyfikacji i rozwoju prawa przemysłowego w Polsce. W Małopolsce

3 Austriacka ustawa o przemyśle fabrycznym i przemysłowym(Gewerbeordnungen) z roku 1859, Niemiecka ustawa o przemyśle fabrycznym i przemysłowym (Gewerbeordnungen) z roku 1869, Postanowienie Księcia Namiestnika Królewskiego z 31 grudnia 1816 roku urządzające zgromadzenie rzemieślnicze, Postanowienie księcia Namiestnika Królewskiego z 1817 roku o urządzeniu kupiectwa, Rosyjska ustawa o przemyśle z roku 1913 oraz Rosyjska ustawa handlowa z roku 1911.

${ }^{4}$ Każdy obywatel ma wolność obrania sobie na obszarze Państwa miejsca zamieszkania i pobytu, przesiedlania się i wychodźstwa, niemniej wolność wyboru zajęcia i zarobkowania oraz przenoszenia swej własności. Ograniczenie tych praw może wprowadzić tylko ustawa. Art. 101 Ustawy z dnia 17 marca 1921 roku Konstytucja Rzeczypospolitej Polskiej (Dz.U. Nr 44, poz. 267)

5 A. Dobiecki, R. Śląski, Polska ustawa przemysłowa z objaśnieniami, Poznań 1927, s. 102. 
podniesiono zarzut, iż projekt ustawy nie przewidywał na przykład obowiązku przynależności do organizacji korporacji przemysłowych i cechów rzemieślniczych. Zakwestionowano także listę rodzajów przemysłu podlegającego obowiązkowi koncesyjnemu. Przedstawiciele sfer przemysłowych b. Królestwa domagali się natomiast zupełnego i bezwarunkowego uwzględnienia tezy wolności przemysłowej, której ograniczenie mogłoby wynikać jedynie z uwagi na interes państwowy i bezpieczeństwo publiczne. $Z$ terenów województw zachodnich, wpłynął postulat szerokiego oparcia nowych regulacji na rozwiązaniach niemieckiej ustawy przemysłowej ${ }^{6}$. Brak jednolitego i wspólnego stanowiska $\mathrm{w}$ przedmiocie regulacji prawa przemysłowego zmusiło ustawodawcę do przeprowadzenia ponownej społecznej ankiety ustnej w dniach 20 maja i 19 lipca 1924 roku.

Po uzgodnieniu stanowiska ze wszystkimi zainteresowanymi stronami projekt ustawy, uchwałą Rady Ministrów z 29 kwietnia 1925 roku został przedłożony Sejmowi ${ }^{7} .5$ czerwca 1925 roku, projekt został przekazany Komisji Przemysłowo-Handlowej do pierwszego czytania. Prace w Komisji rozpoczęły się 3 lutego 1926 roku ogólną rozprawą nad projektem ustawy, następnie na posiedzeniu 4 lutego 1926 roku oraz 25 lutego, 4, 11, 18, 26 marca, 15, 16, 21 i 29 kwietnia 1926 roku omówiono pierwsze 54 artykuły projektu ustawy. Komisja nie dokończyła swojej pracy, gdyż w lipcu 1926 roku, projekt wycofano z Sejmu i przeredagowano go na rozporządzenie Prezydenta Rzeczypospolitej. Taki obrót sprawy wymusił ponowne poddanie projektu ankiecie, co nastapiło w dniu 14 września 1926 roku. Zmieniony projekt w listopadzie 1926 roku przekazano Ministrowi Sprawiedliwości oraz Radzie Prawniczej do zaopiniowania, która jednak nie wywiązała się z tego obowiązku z powodu nadmiaru pracy. Projekt przekazano więc do zaopiniowania Biuru Prawnemu funkcjonującemu przy Prezesie Rady Ministrów. Zaopiniowany projekt został

\footnotetext{
6 Tamże, s. 103-104.

7 Faktyczne przekazanie projektu nastąiło 4 maja 1925 roku przez ówczesnego Ministra Przemysłu i Handlu Józefa Kiedronia (druk sejmowy 1912). M. Lewy, Kilka uwag z powodu Rozporzqdzenia Prezydenta Rozporzadzenia o prawie przemysłowem z 7 czerwca 1927 roku, Warszawa 1927, s. 3.
} 
przyjęty przez Radę Ministrów 27 kwietnia 1927 roku, a dnia 7 czerwca 1927 roku został podpisany przez Prezydenta jako rozporządzenie Prezydenta Rzeczypospolitej o prawie przemysłowem, z mocą obowiązującą od dnia 16 grudnia 1927 roku $^{8}$.

Prawo przemysłowe nie zawierało jednak przepisów typowych dla okresu kapitalizmu pierwszej ćwierci XX w., a to z uwagi na ówczesny układ stosunków gospodarczych, które nadały mu niejednokrotnie charakter archaiczny w przedmiocie niektórych regulacji. Istotnym novum wprowadzonym przez nowe przepisy był obowiązek uzyskania uprawnienia przemysłowego do wykonywania określonego przemysłu na podstawie zgłoszenia o rozpoczęciu prowadzenia przemysłu. Do dnia wejścia w życie ustawy nieznane było w przemyśle niekoncesjonowanym, pojęcie uprawnienia przemysłowego. Do 16 grudnia 1927 roku wykonywanie zajęcia zarobkowego podlegało ogólnej zasadzie swobody jej podejmowania i nie podlegało żadnym istotnym ograniczeniom, szczególnie tym o charakterze formalnym. Podjęcie działalności nie wiązało się z obowiązkiem zgłaszania i zawiadamiania o tym jakiejkolwiek władzy, co nie wykluczało jednak obowiązku zgłoszenia wynikającego np. z przepisów podatkowych czy budowlanych?

Każdy funkcjonujący akt prawny musi czynić zadość wymogom i potrzebie czasu. Nie może być zawieszony w próżni. Pomimo wieloletnich prac nad prawem przemysłowym ulegało ono częstym nowelizacją. Najistotniejsze i największe zmiany wprowadzała ustawa z 10 marca 1934 roku $^{10}$, która dostosowywała przepisy prawa przemysłowego do aktów prawnych wydanych po dniu 16 grudnia 1927 roku. Dodatkowo usunięto różnice interpretacyjne powstałe na tle thumaczenia przepisów rozporządzenia. Ostatecznie nowela dostosowała

${ }^{8}$ A. DobIECKI, R. ŚLĄSKI, op. cit., s. 103-106.

${ }^{9}$ M. Lewy, Kilka uwag z powodu Rozporzqdzenia Prezydenta Rzeczypospolitej o prawie przemystowem z dnia 7 czerwca 1927 roku, «Gazeta Sądowa Warszawska» 29/1927, s. 394.

${ }^{10}$ Ustawa $\mathrm{z}$ dnia 10 marca 1934 roku o zmianie rozporządzenia Prezydenta Rzeczypospolitej z dnia 7 czerwca 1927 roku o prawie przemysłowym. Dz.U. Nr 40, poz. 350 
przepisy do wymagań dotyczących organizacji przemysłu oraz państwowej administracji przemysłowej.

Co się tyczy obowiązywania prawa przemysłowego na terenie województwa śląskiego, to zgodnie z art. 198 tego prawa oraz przepisem art. 8a ustawy konstytucyjnej zawierającej Statut Organiczny Województwa Śląskiego ${ }^{11}$, kwestie jej obowiązywania na terenie Śląska uzależniono od zgody Sejmu Śląskiego wyrażonej w drodze uchwały. Powołując się na oświadczenie Prezesa Rady Ministrów z dnia 12 lipca 1933 roku w sprawie wyrażenia zgody Sejmu Śląskiego na wejście w życie na obszarze województwa śląskiego rozporządzenia Prezydenta Rzeczypospolitej z dnia 7 czerwca 1927 roku o prawie przemysłowem, Sejm Śląski ustawą z dnia 17 maja 1933 roku ogłoszoną w Dzienniku Ustaw Śląskich z dnia 25 maja 1933 roku nr 15, poz. 27, wyraził zgodę na wejście w życie rozporządzenia o prawie przemysłowem na jego terenie, z mocą obowiązującą od 1 lipca 1933 roku.

\section{POJĘCIE PRZEMYSŁU I ZAKRES STOSOWANIA PRAWA PRZEMYSŁOWEGO}

Definicja legalna przemysłu wyznaczająca zakres stosowania prawa przemysłowego, wzorowana na osiagnięciach judykatury niemieckiego prawa przemysłowego, definiowała go jako wszelkie zatrudnienie lub przedsiębiorstwo, wykonywane samoistnie, zarobkowo oraz zawodowo, bez względu na to, czy było ono działalnością wytwarzającą, przetwarzająca, handlową czy też usługową.

Analizując powyższą definicję, mówiąc o przemyśle (jego prowadzeniu) rozumiemy przez to zatrudnienie lub prowadzenie przedsiębiorstwa w zakresie wytwarzania, przetwarzania, handlu i usług z zastrzeżeniem, że te miało charakter zarobkowy, zawodowy i wykonywane były w sposób samoistny.

Przedsiębiorstwo lub zatrudnienie musiało być prowadzone w sposób zarobkowy, czyli musiało być nastawione na zysk. Obojętne było jednak, czy takowy zysk został osiagnięty. Wystarczyła sama nadzie-

${ }^{11}$ Ustawa Konstytucyjna z 15 lipca 1920 roku zawierająca Statut Organiczny Województwa Śląskiego, Dz.U. Nr 73, poz. 497 ze zm. 
ja, że dany przemysł przyniesie zysk, bez względu na jego wysokość. Sam zysk nie musiał mieć charakteru gotówkowego.

Działalność przemysłowa musiała mieć bezwzględnie charakter zawodowy, czyli trwały. Czynności bazujące na okolicznościach jednorazowego zarobkowania nie miały charakteru zawodowego. Oceniając, czy dana działalność miała charakter zawodowy, miarodajny nie był jedynie czas, gdyż istniały tak zwane prace sezonowe, które ze swej natury rzeczy trwały jedynie pewien okres a cechowały się przesłanką zawodowości ${ }^{12}$.

Mówiąc o samoistności prawnej należy przez to rozumieć samoistność zatrudnienia jak i przedsiębiorstwa. Tym samym, poprzez samoistne prowadzenie przemysłu należało rozumieć zarówno podejmowanie działań we własnym imieniu, na własny rachunek, jak i na własną odpowiedzialność, nie będąc zastępcą przemysłowca ani pracownikiem zatrudnionym na podstawie umowy o pracę ${ }^{13}$.

Z przytoczonej powyżej definicji przemysłu wynika wprost, że ta odnosiła się nie tylko do przemysłu w ścisłym tego słowa znaczeniu, czyli do zatrudnienia lub prowadzenia przedsiębiorstwa $\mathrm{w}$ zakresie wytwarzania, przetwarzania, handlu i usług, ale również do wszelkiego zatrudnienia zarobkowego wykonywanego samoistnie i zawodowo.

Niestety, zdefiniowane pojęcie przemysłu nie było jednoznaczne z określeniem granic stosowania prawa przemysłowego. Ustawodawca dosyć szeroko ograniczył zakres jego obowiązywania mocą przepisu art. 2 prawa przemysłowego w którym to enumeratywnie wymienił dziedziny niebędące przemysłem $\mathrm{w}$ rozumieniu prawa przemysłowego. Wyznaczono granice stosowania prawa przemysłowego wyłą-

12 Orzeczenie Sądu Najwyższego z 18 maja 1933 roku, II 4K 253/33, Zbiór Orzeczeń, nr 141/33.

${ }_{13}$ Zastępca przemysłowca nie był samoistnym przemysłowcem. O ustanowieniu zastępcy należało zawsze powiadomić organy władzy przemysłowej I instancji, podając imię i nazwisko, wiek oraz przynależność państwową. W przypadku przemysłu koncesjonowanego oraz rzemiosła należało dodatkowo przedstawić, iż zastępca posiada stosowne uprawnienia do samoistnego prowadzenia danego przemysłu lub rzemiosła. S. KŁusek, W. Gaertner, Polskie ustawodawstwo przemysłowe, Poznań 1930, s. 25. 
czały spod jego obowiązywania między innymi: produkcję pierwotna, wolne zawody, przedsiębiorstwa regulowane przepisami ustaw górniczych czy te zastrzeżone ustawowo wyłącznie państwu.

Niewątpliwie wyłączenie powyższych dziedzin, zarówno z uwagi na kryterium podmiotowe, jak i przedmiotowe, spod obowiązywania przepisów prawa przemysłowego nie było chyba do końca uzasadnione ze względów czysto gospodarczych. To co jednak uzasadniało działania ustawodawcy, to fakt że większość tych dziedzin w dniu wejścia $\mathrm{w}$ życie prawa przemysłowego została już uregulowana $\mathrm{w}$ innych ustawach, rozporządzeniach lub w utrzymanych w mocy przepisach dzielnicowych.

\section{ZASADA WOLNOŚCI PRZEMYSŁOWEJ}

Ustawodawca, o czym było już mowa wcześniej, w przepisie art. 3 urzeczywistnił zasadę konstytucyjną wyrażoną w art. 101 Konstytucji marcowej, zgodnie z którą prowadzenie przemysłu było wolne i dozwolone każdemu, o ile przepisy prawa przemysłowego nie przewidywały w tym zakresie wyjątków lub ograniczeń.

Użycie stwierdzenia „dozwolone każdemu” wskazywało wprost, że przyznana $\mathrm{w}$ przepisie prawa przemysłowego wolność prowadzenia przemysłu nie odnosiła się jednak do organizacji i sposobu jego wykonywania, lecz do osób zarówno fizycznych jak i prawnych, które swobodnie mogły poświęcić się działalności przemysłowej, nie ulegając żadnym ograniczeniom $\mathrm{z}$ wyjątkiem tych wyrażonych $\mathrm{w}$ samym prawie przemysłowym ${ }^{14}$. Zasada ta nie odnosiła się więc do warunków i sposobu prowadzenia danego rodzaju przemysłu, gdyż te podlegały wielu ograniczeniom, wynikającym między innymi z samego prawa przemysłowego jaki i ustaw podatkowych, celnych, o monopolach państwowych czy o ochronie pracy.

Mając na uwadze ogólną doktrynę prawa przemysłowego, ograniczenia te możemy podzielić na dwie podstawowe grupy, to jest ogra-

${ }^{14}$ Jurysprudencja Najwyższego Trybunału Administracyjnego. Prawa nabyte w prawie przemysłowym, «Gazeta Sądowa Warszawska» 49/1933, s. 632. 
niczenia wynikające $\mathrm{z}$ umów oraz ograniczenia ustawowe (prawne). Ograniczenie umowne to indywidualne zrzeczenie się prawa wykonywania przemysłu na podstawie umowy. Jedna strona umowy względem drugiej zobowiązywała się nie wykonywać określonego przemysłu. Ograniczeniem umownym była również tak zwana. klauzula konkurencyjna. Do ograniczeń ustawowych można zaliczyć regulacje $\mathrm{w}$ zakresie dostępu do przemysłu poprzez wprowadzenie obowiązku uzyskania np. koncesji, licencji czy wizy. Z uwagi na kryterium podmiotowe ograniczenia dotyczyły np. cudzoziemców, osób duchownych czy urzędników państwowych.

Faktycznie rzecz biorąc wolność przemysłowa w Polsce, z uwagi na szeroki katalog ograniczeń w sferze dostępu do przemysłu oraz jego wykonywania była zasada, której postanowienia nie znalazły w mojej opinii - realnego odzwierciedlenia w rzeczywistości. Szeroki katalog przemysłów koncesjonowanych, skomplikowana procedura w przedmiocie zatwierdzania urządzeń zakładów przemysłowych, obowiązek wykazywania się doświadczeniem i umiejętnościami zawodowymi, uznaniowość w wydawaniu decyzji administracyjnych przez władze przemysłowe, czy ostatecznie szerokie uprawnienia izb przemysłowo handlowych, doprowadziło w ostseczności do sytuacji kiedy to przepisy prawa przemysłowego zamiast wpływać pozywanie na rozwój przemysłu w Polsce, zaczęły go blokować. Wniosek taki wypływa również z faktu zawiłości przepisów, które nie zawsze były jasne dla zwykłego, przeciętnego przemysłowca ${ }^{15}$.

${ }^{15} \mathrm{~W}$ ocenie ustawodawcy ustalona w Konstytucji marcowej zasada wolności przemysłowej została ujęta w prawie przemysłowym w możliwie najszerszy sposób. Pewnym ograniczeniom podlegała ona jedynie w sferze przemysłu okrężnego oraz niektórych rodzajów przemysłu wymienionych w art. 8 prawa przemysłowego których wykonywanie ze względu na ważny interes państwowy było dozwolone dopiero po uzyskaniu pozwolenia władzy przemysłowej (koncesji, licencji). Dotyczyło to także rzemiosła, pomimo przewidzianego prawem przemysłowym obowiązku wykazania się uzdolnieniami zawodowymi. W sytuacji gdy ktoś rozpoczął wykonywanie rzemiosła bez wykazania się stosownym uzdolnieniem, organ władzy przemysłowej zabraniał ex post dalszego jego wykonywania. Należy jednak pamiętać, że ten sam organ uprawniony był do zwolnienia od wykazania się stosownym uzdolnieniem. A. DobIECKI, R. ŚLĄSKI, op. cit., s. 112-113. 


\section{WŁADZE PRZEMYSŁOWE}

Sprawne funkcjonowanie administracji przemysłu było niezwykle istotne z punktu widzenia rozwoju państwa, którego gospodarka po odzyskaniu niepodległości była w bardzo złym stanie. Prawidłowo i sprawnie funkcjonująca administracja przemysłowa (zarówno ta zespolona jak i niezespolona), poprzez swoje działania miała pozytywnie wpływać na rozwój gospodarczy odrodzonego państwa polskiego. Założenie to jest tym bardziej istotne, iż odnosi to do gospodarki dwudziestolecia międzywojennego, kiedy to nie udało się osiągnąć poziomu produkcji sprzed wybuchu pierwszej wojny światowej. W wyniku działań wojennych prawie jedna piąta majątku narodowego została zniszczona ${ }^{16}$.

Ustawodawca postanowił nie powoływać odrębnych organów administracyjnych, którym powierzyłby pełnienie roli władz przemysłowych I i II instancji, przekazując te zadania, co do zasady ogólnej, istniejącym organom terenowej administracji rządowej o kompetencjach ogólnych, to jest staroście i wojewodzie (Komisarzowi Rządu m.st. Warszawy).

Generalnie w świetle przepisu art. 131 prawa przemysłowego władzą przemysłową I instancji był starosta ${ }^{17}$. Od zasady tej istniało jednak wiele wyjątków. W miastach Warszawa, Łódź, Wilno, Poznań, Toruń, Bydgoszcz, Grudziądz, Katowice i Królewska Huta, władzami przemysłowymi I instancji były z mocy prawa zarządy miejskie ${ }^{18}$. Sprawy zlecone rozpatrywane były jednoosobowo przez przełożonego gminy (prezydenta, burmistrza) przy pomocy innych członków zarządu. Inaczej sytuacja przedstawiała się w Białymstoku, Częstochowie, Gnieźnie, Inowrocławiu, Lublinie, Radomiu i Sosnowcu, które admi-

${ }^{16}$ E. KwiatKowski, Fizyka gospodarczo-polityczna Polski, «Przemysł i Handel» 9/1928, s. 3.

${ }^{17}$ Chodziło o starostów powiatowych, a nie grodzkich.

18 Zmianę dawnego określenia magistraty na zarządy Miejskie wprowadzono nowelą prawa przemysłowego z 1934 roku, dostosowując jej postanowienia. do ustawy z 23 marca 1933 roku o częściowej zmianie ustroju samorządu terytorialnego (Dz.U. z 1933 r. Nr 35, poz. 294). 
nistracyjnie były odrębnymi powiatami miejskimi dla celów administracji ogólnej ${ }^{19}$. W Gnieźnie i Inowrocławiu władzą przemysłową I instancji był prezydent miasta. Natomiast w Białymstoku, Częstochowie, Lublinie, Radomiu i Sosnowcu funkcje te sprawowali starostowie grodzcy. W mieście Gdyni na czele powiatu stał komisarz rządu, który z urzędu był organem władzy przemysłowej I instancji ${ }^{20}$.

Zakres kompetencji organów I instancji określono na zasadzie ich domniemania, to jest wydawanie orzeczeń i zarządzeń we wszystkich sprawach niezastrzeżonych wyższym władzom przemysłowym. Władze te nie zostały powołane do orzekania w innych sprawach, unormowanych w odrębnych ustawach lub rozporządzeniach, którym podlegało prowadzenie przemysłu. Organ właściwy, wydając decyzję w sprawie, zobowiązany był wziąć pod uwagę regulacje przepisów szczególnych i współpracować z władzami powołanymi do działania na podstawie odrębnych przepisów (władze sanitarne, skarbowe, weterynaryjne, drogowe, kolejowe, wodne, inspekcja pracy itp.).

Do katalogu podmiotów będących organami władzy przemysłowej I instancji należy również zaliczyć wojewodę (władza przemysłowa wojewódzka), w sytuacji gdy ten wydawał zarządzenia i orzeczenia w sprawach przewidzianych dla władzy przemysłowej wojewódzkiej właściwej w I instancji, z tą jednak różnicą, że wówczas katalog kompetencji nie określono poprzez domniemanie, lecz były one szczegółowo określone w przepisach prawa przemysłowego, to jest: wydawanie orzeczeń i zarządzeń we wszystkich sprawach, w których prawo decyzji było im zastrzeżone poszczególnymi artykułami prawa przemysłowego ${ }^{21}$. Niewątpliwie katalog organów i instancji zamyka minister przemysłu i handlu, który w sytuacjach przewidzianych przepisami prawem przemysłowym wydawał decyzje w I instancji.

${ }_{19}$ Rozporządzenie Rady Ministrów z dnia 27 kwietnia 1932 r. w sprawie powiatów miejskich (Dz.U. Nr 41, poz. 408).

${ }^{20}$ Rozporządzenie Prezydenta Rzeczypospolitej z dnia 24 listopada 1930 r. o ustroju miasta Gdyni (Dz.U. Nr 80, poz. 630).

${ }^{21}$ Wydawanie pozwoleń i koncesji na określone rodzaje przemysłu, zatwierdzanie projektów urządzenia zakładu przemysłowego czy np. wydawanie uprawnień na targi wielkie. 
Do katalogu organów władzy przemysłowej II instancji zaliczamy przede wszystkim wojewodę w zakresie rozstrzygania w II i ostatniej instancji odwołań od zarządzeń i orzeczeń władz przemysłowych wydawanych w I instancji oraz Ministra Przemysłu i Handlu, gdy ten rozstrzygał w II instancji odwołania od zarządzeń i orzeczeń wydanych w I instancji przez wojewodę.

\section{RODZAJE PRZEMYSEU}

Zgodnie z przyjętą nomenklatura prawa przemysłowego, ustawa dzieliła przemysł na dwie podstawowe kategorie:

- ze stałą siedzibą (prowadzony w zakładach przemysłowych) - przemysł koncesjonowany i niekoncesjonowany (wolny) oraz rzemiosło;

- bez stałej siedziby, tzw. okrężny.

Niejednokrotnie jako trzecią kategorię przemysłu uznawano przemysł prowadzony na targach.

Ilekroć w rozporządzeniu była mowa o ,przemyśle ze stałą siedziba", chodziło o wykonywanie przemysłu w specjalnie do tego przystosowanym zakładzie przemysłowym ${ }^{22}$.

\section{Przemysł wolny}

Rozpoczęcie prowadzenia przemysłu ze stałą siedzibą, które nie podlegało obowiązkowi koncesyjnemu wymagało, zgłoszenia rozpoczęcia prowadzenia przemysłu władzy przemysłowej I instancji właściwej dla miejsca siedziby zakładu przemysłowego. Obowiązek ten nałożono zarówno na osoby fizyczne, jak i prawne. Osoba fizyczna w zgłoszeniu zobowiązana była do podania następujących danych: imię i nazwisko, przynależność państwową, miejsce zamieszkania, rodzaj przemysłu, siedzibę (lokal) oraz firmę przedsiębiorstwa. W przypadku osób prawnych należało podać jeszcze rodzaj działalności, siedzibę, kapitał zakładowy, zdolność produkcyjną przedsiębiorstwa,

${ }^{22}$ Co ciekawe do wykonywania przemysłu ze stałą siedzibą nie było wymagane posiadanie lokalu przemysłowego, do tej kategorii ustawodawca zliczył również dorożkarzy oraz posłańców 
skład pierwszego zarządu lub skład osobowy grona założycieli oraz firmę przedsiębiorstwa.

Organ władzy przemysłowej bez zbędnej zwłoki wydawał potwierdzenie odbioru zgłoszenia $\mathrm{z}$ podaniem numeru porządkowego, pod którym został dokonany wpis w rejestrze uprawnień przemysłowych, jeżeli nie sprzeciwiały się temu przepisy prawa przemysłowego w przedmiocie ograniczeń prowadzenia przemysłu ${ }^{23}$. Co ciekawe, dopiero po dokonaniu zgłoszenia badano, czy zgłaszający posiadał warunki samoistnego prowadzenia przemysłu. Jeżeli zgłoszono przemysł wolny, który w opinii władzy przemysłowej był rzemiosłem, wzywano do wykazania się uzdolnieniem zawodowym w terminie wskazanym na wezwaniu. Jeżeli uzdolnienie takie zostało wykazane, wystawiono kartę rzemieślniczą.

\section{Przemysł koncesjonowany}

Wspominałem już wcześniej, iż analizując przepisy prawa przemysłowego, dochodzimy ostatecznie do wniosku, iż ustawodawca zdecydował się stosunkowo szeroko ograniczyć sferę wykonywania (dostępu) przemysłu. Podstawowym instrumentem, za pomocą którego cel ten miał być osiągnięty był obowiązek uzyskania koncesji na określonego rodzaju przemysł. Sam katalog przemysłów koncesjonowanych określony w prawie przemysłowym, który był niezwykle rozbudowany ${ }^{24}$. Ustawodawca niejednokrotnie starał się uzasadnić takie

${ }^{23}$ Potwierdzenie odbioru zgłoszenia wydawano w formie pisemnego wyciagu.

${ }^{24}$ Zgodnie $\mathrm{z}$ art. 8 prawa przemysłowego obowiązek koncesyjny obejmował: przedsiębiorstwa instalacji wodociagowych i kanalizacyjnych, gazowych i elektrycznych, przemysł kominiarski, wyrobu wszelkich materiałów i przedmiotów pirotechnicznych i wybuchowych, wyrobu broni i amunicji, wyrobu i sprzedaży statków powietrznych, przemysłu gospodniego, pośrednictwa w nabywaniu biletów podróży kolejami, okrętami itp., ekspediowanie bagażu podróżnego oraz działalność, polegającą na świadczeniu usług, które miały udogodnić podróż, dochodzenie roszczeń powstałych w wyniku umowy o przewóz towarów, do zarządów kolejowych i innych zakładów przewozowych, przedsiębiorstwa informacyjne o stosunkach gospodarczych, handel starociami, przedsiębiorstwa sprzedaży ruchomości w drodze przetargu, przemysł oprawczy, przedsiębiorstwa wyrobu syntetycznych barwników organicznych oraz 
stanowisko, twierdząc że ustalając stosunkowo szeroką listę przemysłów, których wykonywanie uzależnione było od uzyskania (pozwolenia) koncesji, kierował się zasadą, iż tylko te rodzaje przemysłu należało poddać przymusowi uzyskania koncesji, których wykonywanie $\mathrm{z}$ uwagi na ważny interes publiczny i bezpieczeństwo państwa należało uzależnić od ściśle określonych warunków. Co ważne i wymaga zaznaczenia, katalog określony w art. 8 nie miał charakteru zamkniętego. Szereg przemysłów poddano obowiązku koncesyjnemu mocą szeregu ustaw oraz rozporządzeń Rady Ministrów.

$\mathrm{Na}$ gruncie prawa przemysłowego wykonywanie przemysłu koncesjonowanego dozwolone było dopiero po uzyskaniu koncesji od właściwej władzy przemysłowej ${ }^{25}$. Strona zainteresowana uzyskaniem koncesji wnosiła podanie o jej udzielenie na piśmie lub ustnie do protokołu, chyba że ustalono wzór urzędowy. Podanie o udzielenie koncesji wnoszone bezwzględnie do organu władzy przemysłowej I instancji (starosty) winno było zawierać: imię i nazwisko, wiek, przynależność państwową, miejsce zamieszkania osoby ubiegającej się o koncesję, dokładne określenie przedmiotu zamierzonego przedsiębiorstwa, miejsce prowadzenia przemysłu, firmę oraz jeżeli było to wymagane, dowód posiadania określonych umiejętności zawodowych.

W określonych sytuacjach ustawodawca uzależniał wydanie koncesji od legitymowania się odpowiednimi umiejętnościami prowadzenia przemysłu koncesjonowanego ${ }^{26}$. W przypadkach zasługujących na szczególne uwzględnienie władza przemysłowa wojewódzka mogła na wniosek izby przemysłowo-handlowej zwolnić osobę ubiegającą

syntetycznych półproduktów organicznych, służących do wyrobu barwników i materiałów wybuchowych, wyrobu syntetycznych barwników organicznych, wyrobu kwasu azotowego, oraz przemysł tragarzy w miastach.

${ }^{25}$ Co do zasady ogólnej był to starosta, chyba że przepis prawa przemysłowego wskazywała, w zakresie danego przemysłu na wojewodę.

${ }^{26}$ Przedmiotową kwestię regulowało rozporządzenie Ministra Przemysłu i Handlu z dnia 9 grudnia 1927 r. wydane w porozumieniu z Ministrami Wyznań Religijnych i Oświecenia Publicznego, Spraw Wewnętrznych, Robót Publicznych, Spraw Wojskowych oraz Komunikacji w sprawie umiejętności zawodowej do prowadzenia przemysłu koncesjonowanego (Dz.U. Nr 111, poz. 943). 
się o koncesję z obowiązku legitymowania się umiejętnością zawodową, jeżeli ta wykazała zadowalające umiejętności i wiedzę do prowadzenia danego przemysłu.

Jeżeli nie zachodziły żadne przeszkody, organ koncesyjny udzielał koncesji ${ }^{27}$. W sytuacji gdy organem koncesyjnym był wojewoda, decyzję w sprawie przesyłano do organu I instancji, którego obowiązkiem było formalne wręczenie petentowi dokumentu koncesyjnego. Sam dokument koncesyjny wydawany był w formie pisemnej i zawierał podstawę prawna, dane koncesjonariusza z dokładnym określeniem przemysłu, miejscem prowadzenia oraz warunków, pod którymi koncesji udzielono.

\section{Rzemiosło}

Rzemiosło było swoistym rodzajem przemysłu ze stałą siedziba, który mógł być wykonywany jedynie sposobem rzemieślniczym (nigdy fabrycznym). Działalność rzemieślniczą można było rozpocząć dopiero po uprzednim otrzymaniu od właściwej władzy przemysłowej I instancji karty rzemieślniczej, która wydawana była dopiero wtedy, gdy osoba ubiegającą się o jej wydanie udowodniła odpowiednie kwalifikacje zawodowe do prowadzenia danego rzemiosła ${ }^{28}$. Kartę należało wydać w terminie do 30 dni, licząc od dnia zgłoszenia o rozpoczęciu wykonywania działalności rzemieślniczej. Samo już jej wydanie następowało $\mathrm{w}$ formie wyciągu ze zgłoszenia (zaświadczenia) z podaniem numeru porządkowego. Odmowa następowała w drodze decyzji administracyjnej.

27 Przeciwny pogląd przedstawiał między innymi M. Lewy, Kilka uwag z powodu Rozporzqdzenia Prezydenta Rzeczypospolitej o prawie przemysłowem z dnia 7 czerwca 1927 roku, Warszawa 1927, s. 13, który twierdził, że wydanie lub odmowa wydania koncesji zależały w zasadzie od uznania władzy przemysłowej.

${ }^{28}$ Nowela prawa przemysłowego z 10 marca 1934 roku wprowadziła istotne obostrzenia w zakresie prowadzenia działalności rzemieślniczej, uzależniając jego rozpoczęcie od uprzedniego uzyskania karty rzemieślniczej. Przez wejściem w życie nowelizacji, można było rozpocząć prowadzenie rzemiosła bez karty, a jedynie wykazać się właściwym uzdolnieniem. Karat wydawana była ex post. 
Niewątpliwie wprowadzenie obowiązku posiadania karty rzemieślniczej, z jednoczesnym obowiązkiem legitymowania się uzdolnieniem zawodowym, było przejawem reglamentacji działalności rzemieślniczej.

\section{Zakłady przemysłowe}

Przemysł wolny oraz koncesjonowany zaliczany był do przemysłów ze stałą siedzibą, to znaczy musiał być wykonywany w zakładach przemysłowych, którym $\mathrm{w}$ rozumieniu przepisów prawa przemysłowego były zarówno budowle, lokale, jak i wszelkie inne miejsca służące do prowadzenia przemysłu w sposób trwały, bez względu na to, czy były zaopatrzone w maszyny lub inne specjalne urządzenia. Zakładem przemysłowym była więc zarówno fabryka jak i warsztat rzemieślniczy, hotel, restauracja, kawiarnia, sklep, każde inne miejsce służące do stałego wykonywania przemysłu.

Niektóre zakłady mogły być uznane za zakłady przemysłowe dopiero po uprzednim zatwierdzeniu projektu urządzenia zakładu przemysłowego. Obowiązek uzyskania decyzji zatwierdzającej projekt nałożono przepisem art. 14 prawa przemysłowego zgodnie z którym do urządzenia zakładu przemysłowego wymagane było uprzednie zatwierdzenie samego projektu, jeżeli zakład przemysłowy używał napędu mechanicznego, gdy jego działalność zagrażała bezpieczeństwu publicznemu, przede wszystkim życiu i zdrowiu pracowników oraz sąsiadów. Projekt urządzenia zakładu przemysłowego zatwierdzała władza przemysłowa I instancji, chyba że przepis prawa przemysłowego wyraźnie zastrzegał to prawo dla władzy przemysłowej II instancji (wojewódzkiej), z uwagi na względy natury technicznej i organizacyjnej.

Władza przemysłowa wojewódzka zatwierdzała projekty urządzenia zakładu przemysłowego między innymi dla: wytwórni prochu strzelniczego, ogni sztucznych, wytwórni krochmalu, wytwórni syropu kartoflanego, hut, odlewni żelaza i innych metali, kotlarni fabryki maszyn i żelaznych konstrukcji budowlanych, zakładów ołowiania, cynkowania i cynowania, wszelkich zakładów przemysłowych działających za pomocą silników parowych, elektrycznych, spalinowych, 
o ile moc tych silników przekraczała $10 \mathrm{KM}$, średnich i wielkich składów olejów mineralnych, zakładów przemysłowych działających za pomocą siły wodnej ponad $50 \mathrm{KM}$ oraz bez względu na ilość KM, jeżeli użytkowały wody płynące, używane do żeglugi i spławu tratew.

Zatwierdzenie projektu przez właściwą władzę przemysłową następowało w drodze decyzji administracyjnej. Sama procedura zatwierdzania projektu mogła odbywać się w dwóch trybach, uproszczonym i zwykłym. Zasadniczo rodzaj postępowania zależał od wielkości i rodzaju produkcji oraz organu który wydawał decyzję w sprawie. W przypadku zakładów enumeratywnie zastrzeżonych dla władzy wojewódzkiej stosowano bezwzględnie procedurę zwykłą, z zastrzeżeniem jednak, że w przypadku niewielkiego zakładu można było zastosować procedurę tzw. uproszczoną. Do pozostałych zakładów przemysłowych, podlegających zatwierdzeniu głównie przez władzę przemysłową I instancji zastosowanie miała procedura uproszczona, w której to nie była wymagana opinia właściwego urzędu gminy oraz nie przeprowadzano postępowania komisyjnego w sprawie.

Uruchomienie zakładu przemysłowego mogło nastapić dopiero po spełnieniu warunków ustalonych prawomocną decyzją zatwierdzającą projekt urządzenia zakładu przemysłowego. O samym uruchomieniu należało poinformować właściwą władzę przemysłową, której przedstawiciel mógł stwierdzić na miejscu, czy urządzenie zakładu przemysłowego odpowiadało warunkom zawartym w prawomocnej decyzji. Polskie prawo przemysłowe nie przewidywało osobnego pozwolenia na uruchomienie zakładu przemysłowego. Stąd też przedsiębiorca, który uzyskał prawomocną decyzję o zatwierdzeniu projektu zakładu przemysłowego, mógł go uruchomić.

Decyzja administracyjna w sprawie zatwierdzenia projektu urządzenia zakładu przemysłowego wygasała na skutek jego nieuruchomienia w przeciagu 5 lat od dnia jej uprawomocnienia oraz gdy przerwa w działaniu zakładu była dłuższa niż 5 lat. Terminy te mogły być przedłużane przez właściwą władzę przemysłową, gdy nastapiło zniszczenie zakładu przemysłowego, a ponowne jego uruchomienie mogło nastąpić dopiero po ponownym uprzednim zatwierdzeniu projektu urządzenia zakładu przemysłowego. Rozwiązanie takie miało swoje 
pełne uzasadnienie. W okresie kilkuletniej przerwy zmianie mogły ulec stosunki natury technicznej lub lokalowej, co mogło wiązać się z wprowadzeniem nowych warunków urządzenia zakładu przemysłowego w porównaniu z pierwotną decyzją.

W decyzji zatwierdzającej projekt urządzenia zakładu przemysłowego należało określić udział stron w pokryciu kosztów rozprawy komisyjnej, jeśli ta była przeprowadzona ${ }^{29}$.

\section{Przemysł okrężny}

Definicję przemysłu okrężnego, podlegającego ścisłej reglamentacji prawnej, zawierał przepis art. 45 prawa przemysłowego, zgodnie z którym było to zatrudnienie zarobkowe, wykonywane samoistnie, zawodowo i osobiście bez stałej siedziby przemysłowej w zakresie sprzedaży towarów, skupywania w celu odsprzedaży towarów u innych osób niż u kupców albo w innych miejscach niż w przeznaczonych do sprzedaży towarów, proponowanie i wykonywanie drobnych świadczeń natury przemysłowej (na przykład drutowanie naczyń, naprawianie parasoli, ostrzenie noży, wprawianie szyb itd.) ${ }^{30}$.

Analizując powyższą definicję, można wyprowadzić z niej cechy charakterystyczne przemysłu okrężnego to jest: zarobkowy charakter, samoistne wykonywanie zatrudnienia, zawodowość zatrudnienia, wykowywane osobiście oraz co najważniejsze, brak siedziby.

Osoba, która zamierzała prowadzić przemysł okrężny, zobowiązana była do uzyskania licencji, której udzielała władza przemysłowa I instancji w formie decyzji administracyjnej. Obowiązek ten wzbudzał wiele kontrowersji co do zasadności reglamentacji tego rodzaju przemysłu. Wprowadzenie obowiązku licencyjnego miało być jednak

29 Zarządzając rozprawę komisyjna, właściwa władza przemysłowa mogła wezwać przedsiębiorcę oraz osoby podnoszące zarzuty do zdeponowania w kasie skarbowej kwot na pokrycie przyszłych kosztów.

${ }^{30}$ Wprowadzona definicja przemysłu okrężnego zastapiła tak zwany handel wędrujący. 
swoistą gwarancją dla kupujących, iż ten ma do czynienia z profesjonalnym przemysłowcem ${ }^{31}$.

Podania o udzielenie licencji można było wnieść pisemnie lub ustnie do protokołu. Obowiązkowo należało dołączyć aktualną fotografię o wymiarach $6 \times 7 \mathrm{~cm}$. Rozpatrując podanie, w pierwszej kolejności sprawdzano czy petent posiadał polskie obywatelstwo. Jego brak był równoznaczny z odmową udzielenia licencji. Od decyzji tej przysługiwało odwołanie.

W przypadku braku przeszkód do udzielenia licencji właściwy organ władzy przemysłowej udzielał jej na okres roku i na obszar danego województwa. Dokument licencji zawierał: imię i nazwisko, miejsce zamieszkania, rok urodzenia oraz szczegółowy opis rodzaju przemysłu okrężnego. Licencję należało mieć zawsze przy sobie i okazywać na żądanie właściwego organu.

Widzimy więc, że uprawnienie do wykonywania przemysłu okrężnego miało ograniczony zakres czasowy i terytorialny, władza przemysłowa wojewódzka uprawniona była jednak do rozszerzenia ważności licencji, wydanej w innym województwie, na swoje terytorium, na okres nie dłuższy niż do końca roku kalendarzowego, na który została wydana. Rozszerzenie ważności licencji na teren innego województwa podlegało zasadzie swobodnej oceny przez władzę przemysłową. Fakt ten jednak nie zwalniał orgazm z podania przyczyn nieuwzględnienia podania. W przypadku uwzględnienia, władza przemysłowa wojewódzka wydawała specjalną wizę, którą umieszczano w książce licencyjnej. Ograniczenia terytorialne przejawiały się poprzez możliwość określenia w licencji powiatów, w których właścicielowi licencji nie można było prowadzić przemysłu okrężnego. Dalej, możliwe było również ograniczenie ważności licencji na obszarze określonej gminy poprzez obowiązek uzyskania dodatkowego zezwolenia (wizy)

${ }^{31}$ M. Lewy, Kilka uwag z powodu Rozporzqdzenia Prezydenta Rzeczypospolitej o prawie przemystowem z dnia 7 czerwca 1927 roku, "Gazeta Sądowa Warszawska» 30/1927, s. 409. 


\section{Targi gminne}

Jedną z ważniejszych form wymiany towarowej w okresie międzywojennym była sprzedaż targowa. Ten szczególny rodzaj pzremysłu uregulowany został w prawie przemysłowym jako szczególny rodzaj przemysłu zastrzeżony dla gminy. Regulacji poddano kwestie związane $\mathrm{z}$ nabywaniem uprawnień targowych, urządzeniem i prowadzeniem targów oraz zakresem obrotu towarowego. Działalność targowa jako forma przemysłu podlegał tym samym jednolitym, ogólnym normom administracyjno-przemysłowym o charakterze reglamentacyjnym. Targi gminne dzieliły się na targi małe (zwykłe, tygodniowe) oraz targi wielkie (powiatowe, wojewódzkie, odpustowe, kiermasze, jarmarki). To co je odróżniało to przede wszystkim asortyment, który tam oferowano. Na targach małych sprzedawano przede wszystkim płody rolne, zwierzęta domowe (małe), naczynia, narzędzia gospodarcze oraz inne przedmioty powszechnego użytku, które ludność zwykła nabywać na targach. Na targach wielkich obrót obejmował wszelkie przedmioty wolnego obrotu towarowego, o ile poszczególne uprawnienia targowe nie ograniczały obrotu towarowego do pewnych towarów, na przykład bydła, wełny, zboża. Oczywiście dozwolony był jednoczesny obrót towarami zastrzeżonymi dla targów tygodniowych.

Podstawowym warunkiem prowadzenia działalności targowej było uzyskanie przez gminę uprawnienia targowego na prowadzenie targowiska w dniach i godzinach ustalonych w regulaminie. Pozwolenia na targi małe udzielała władza przemysłowa I instancji, a na targi wielkie władza przemysłowa wojewódzka. Uzyskanie zezwolenia na targi małe nie legitymowało uprawnienia do prowadzenia targów wielkich i odwrotnie. Wszczęcie postępowania w sprawie udzielenia uprawnienia targowego następowało wyłącznie na wniosek zainteresowanej gminy. Rozstrzygnięcie sprawy następowało w drodze decyzji administracyjnej, w której określano miejsce odbywania się targów w ściśle określonym tzw. dniu targowym.

Istotne z punktu widzenia funkcjonowania targu było ustalenie przepisów porządkowych (policyjnych), którym poddano zarówno tryb oraz ład w zwożeniu towarów na targowiska, zajmowaniu miejsc tar- 
gowych, jak i godziny rozpoczęcia i zakończenia sprzedaży. Rolę tych przepisów spełniały regulaminy targowe uchwalane przez właściwą radę gminy (miasta) w formie uchwały. Był to akt prawa miejscowego regulujący organizację i działanie targowiska. Dla swej ważności wymagał zatwierdzenia przez właściwą władzę przemysłową po wysłuchaniu opinii izby przemysłowo-handlowej, izby rzemieślniczej oraz izby rolniczej. Przedmiotowe opinie nie wiązały organu władzy przemysłowej, miały jedynie charakter pomocniczy w procesie wydawania stosownych decyzji. Zatwierdzanie regulaminów przez władzę przemysłową było typowym aktem nadzoru administracji rządowej nad aktami prawnymi wydawanymi przez organy administracji samorządowej.

\section{REJESTR UPRAWNIEŃ PRZEMYSŁOWYCH}

Rejestry uprawnień przemysłowych prowadziła władza przemysłowa I instancji. Osobno prowadzono rejestr przemysłów niekoncesjonowanych, koncesjonowanych, okrężnych i rzemieślniczych ${ }^{32}$. W rejestrze należało rejestrować bez zbędnej zwłoki każde zgłoszenie wykonywania przemysłu, wydanie koncesji lub licencji. Rejestracji podlegała również każda zmiana wpisu, informacja o otwarciu filii, zmiany siedziby, prowadzeniu przemysłu przez zastępcę lub dzierżawcę jak również zrzeczenie się lub odebranie uprawnienia przemysłowego. Samo zrzeczenie się mogło dotyczyć zarówno przemysłu koncesjonowanego, jak i niekoncesjonowanego. $\mathrm{O}$ zrzeczeniu się uprawnienia należało zawiadomić właściwą władzę przemysłowa I instancji i zwrócić potwierdzenie odbioru zgłoszenia lub kartę rzemieślnicza.

W rejestrze uprawnień przemysłów koncesjonowanych wpisywano jedynie te koncesje, które zostały wydane na podstawie prawa przemysłowego. O każdym zarejestrowanym podmiocie organ rejestrowy zawiadamiał właściwą władzę podatkową, izbę przemysłowo handlową oraz izbę rzemieślniczą. Należy tutaj zaznaczyć, iż przepisy prawa

${ }^{32}$ Rejestr uprawnień dla przemysłów rzemieślniczych wprowadzono nowelą z 10 marca 1934 r. 
przemysłowego nie przewidywały żadnej szczególnej formy i treści tego zawiadomienia.

Podsumowując, władza przemysłowa I instancji prowadziła następujące rejestry:

1. Rejestr koncesji;

2. Dwa rejestry potwierdzeń zgłoszeń: a) dla przedsiębiorstw handlowych, b) dla przedsiębiorstw wytwórczych wolnych fabrycznych;

3. Rejestr kart rzemieślniczych;

4. Rejestr zakładów przemysłowych wymagających osobnego zatwierdzenia w myśl art. 14 i 16 prawa przemysłowego;

5. Rejestr licencji dla przemysłów okrężnych;

6. Rejestr legitymacji dla komiwojażerów i samodzielnych ajentów handlowych.

Rejestry wskazane w pkt 1, 2, 3, 5 i 6 były tak zwanymi rejestrami osobowymi, natomiast z pkt 4 był rejestrem rzeczowym.

\section{KORPORACJE PRZEMYSŁOWE}

Korporacje przemysłowe zaliczane do stowarzyszeń wolnych specjalnych były dobrowolnymi zrzeszeniami osób samodzielnie prowadzących przemysł, powołanymi w celu pielęgnowania ducha łączności, utrzymywania i podnoszenia godności zawodowej, sprawowania pieczy nad utrzymaniem dobrego stosunku miedzy członkami korporacji i ich pracownikami, prowadzenia wykazów wolnych miejsc pracy w przedsiębiorstwach, opieki nad sprawami młodzieży przemysłowej w trakcie nauki zawodu ${ }^{33}$.

Powstanie korporacji nie było obwarowane zgodą organu administracji lub rejestracją sądową, gdyż te powstawały jako wyraz woli

${ }^{33}$ Zadaniami o charakterze fakultatywnym było: popieranie i urządzanie szkół, kursów, odczytów i t. p. celem wykształcenia zawodowego członków korporacji i ich pracowników oraz uczniów; tworzenie kas i funduszów zapomogowych dla członków korporacji i ich rodzin i pracowników; gospodarcze popieranie przemysłowej pracy członków korporacji przez utrzymywanie wspólnych warsztatów pracy, składów surowców, półfabrykatów i wzorów, wspólnych magazynów sprzedaży oraz zakładanie kas zaliczkowych. 
swoich założycieli. Wzorem jednak rozwiązań dzielnicowych, przyjęto zasadę zatwierdzania statutu przez władzę przemysłową wojewódzką w trybie nadzoru. Jeżeli okręg korporacji rozciagał się według statutu na gminy i powiaty nie należące do jednego województwa, ten podlegał zatwierdzeniu dopiero po uzyskaniu stosownego zezwolenia przez Ministra Przemysłu i Handlu. Samo jednak zatwierdzenie było jedynie czynnością formalna, formą sprawdzenia, czy postanowienia statut nie naruszają obowiązujących przepisów prawa. W przeciwnym razie wojewoda nie mógł odmówić jego zatwierdzenia. Wyłączono w ten sposób prawo swobodnej oceny przez organ administracji. Od decyzji odmownej przysługiwało odwołanie do Ministra Przemysłu i Handlu.

Korporacja była osobą prawną, mogła tym samym nabywać majątek ruchomy i nieruchomości, zawierać umowy, zaciagać zobowiązania, pozywać i być pozywana. Co ciekawe, o czym była mowa już powyżej, prawo przemysłowe nie przewidywało rejestracji sądowej jako warunku uzyskania osobowości prawnej. Rozwiązanie takie zostało przyjęte $\mathrm{z}$ racji, że korporacje przemysłowe działające $\mathrm{w}$ oparciu o przepisy ustawy przemysłowej były organizacjami sui generis, różniącymi się zasadniczo od wszelkich innych związków i stowarzyszeń, dla których również nie przewidziano obowiązku rejestracji sądowej.

Korporacje mogły łączyć się w związki, których zadaniem było ułatwianie korporacjom spełniania ich zadań ustawowych. Dodatkowo mogły one występować z wnioskami we wszystkich sprawach istotnych z punktu widzenia ich funkcjonowania jak i dotyczących sfery przemysłu. Związek korporacji posiadał osobowość prawną, a za swe zobowiązania odpowiadał całym swoim majątkiem.

Dział V prawa przemysłowego nowelą z 10 marca 1934 roku przeszedł gruntowną zmianę, łącznie z otrzymaniem całkowicie nowej nazwy: „Zrzeszenia przemysłowe oraz ich związki”. Nowela zmieniła w sposób diametralny podstawy prawne funkcjonowania korporacji przemysłowych oraz ich związków. Uznano, że na gruncie przepisów obowiązujących do dnia wejścia wskazanej nowelizacji, korporacje nie spełniały swojej podstawowej roli, do której zostały powołane, 
a to z uwagi na fakt, że te stały się organizacjami społecznymi a nie gospodarczymi.

W uzasadnieniu do zmian podano, że nowe przepisy miały pomóc definitywnie zakończyć etap funkcjonowania korporacji, które uzyskały bardziej cechowy charakter i nie znalazł uznania w sferze tzw. wielkiego przemysłu, który szukał innych form organizacyjnych: stowarzyszenia, spółki kapitałowe. Zauważono również, że istniejące korporacje nie przyczyniły się do podniesienia poziomu technicznego przemysłu oraz rozwoju współpracy różnych rodzajów przemysłu w zakresie produkcji. Cel ten miał zostać osiagnięty poprzez dostosowanie organizacji przemysłowych do warunków zespolonego i jednolitego organizmu gospodarczego państwa i poddanie ich kontroli legalizacyjnej i rejestracyjnej ministra przemysłu i handlu ${ }^{34}$.

\section{PostanOWIENIA KARNE}

Sankcjami przewidzianymi tytułem naruszenia postanowień prawa przemysłowego nakładanymi $\mathrm{w}$ drodze administracyjnej były: upomnienie, grzywna do 1000 zl, areszt do 14 dni, odebranie koncesji lub licencji na czas określony lub na stałe. Od 1934 podwyższono kary grzywny do $3000 \mathrm{zl}$, a aresztu do 3 miesięcy w przypadku naruszenia przepisów w sferze wykonywania przemysłu koncesjonowanego tzw. „wywiadowi gospodarczych”. Niższy wymiar kar wprowadzono w przypadku naruszenia przepisów regulaminów targowych tj. grzywny do $50 \mathrm{zl}$, aresztu do $3 \mathrm{dni}^{35}$. Przepisy karne oparto na zasadzie karania jedynie $\mathrm{w}$ drodze administracyjnej. Wniosek taki wypływa

\footnotetext{
34 S. KŁusek, W. Gaertner, Polskie prawo przemystowe, Poznań 1935, s. 149.

${ }^{35}$ Wprowadzenie przepisów karnych za naruszenie regulaminów targowych uzupełniło istotną lukę przede wszystkim w możliwości karania osób kupujących na targach czy też sprzedawców, którzy handlowali na targu, nie prowadząc przemysłu. Dodatkowo problematyczne było, czy sankcje przewidziane w art. 126 ust. 1 odnosiły się pierwotnie do regulaminów targowych, to jest czy należało je tym samym uważać za przepisy wykonawcze prawa przemysłowego. Nowy przepis eliminował tę lukę. Karze grzywny do 50 zł lub aresztu do 3 dni podlegał zarówno sprzedawca, jak i kupujący oraz każda osoba znajdująca się na targowisku, która naruszała jego regulamin.
} 
z wykreślenia z treści art. 126 w roku 1934 sformułowania „o ile dany czyn nie jest zagrożony karą w powszechnych ustawach karnych”.

Karom przewidzianym w przepisach prawa przemysłowego podlegał każdy, kto naruszył jego postanowienia, to jest nie tylko przemysłowiec, lecz także osoby, które prowadziły przemysł w sposób niesamoistny, na przykład ustanowieni zastępcy przemysłowca z zastrzeżeniem jednak, że karze wówczas podlegał również sam przemysłowiec.

Przewidziana $\mathrm{w}$ prawie przemysłowym kara upomnienia nie miała prawnego usankcjonowania w przepisach o postępowaniu karno administracyjnym czy kodeksie postępowania karnego. Była swoistym ostrzeżeniem, stosowanym w przypadku drobnych uchybień, popełnionych po raz pierwszy oraz o charakterze nieumyślnym.

W sytuacji gdy organ władzy przemysłowej uznał za wskazane nałożenie grzywny w wysokości do 50 zł lub karę aresztu do 3 dni, mógł to uczynić w drodze tak zwanego nakazu karnego, od którego ukaranemu przysługiwało prawo sprzeciwu w ciągu 7 dni od dnia doręczenia nakazu, w przeciwnym razie stawał się on prawomocny i wykonalny. W przypadku wniesienia sprzeciwu organ zarządzał przeprowadzenie postępowania karno-administracyjnego zwyczajnego. Dodatkowo wraz z wniesieniem sprzeciwu nakaz karny tracił swą moc, a organ przeprowadzający rozprawę orzekał od nowa o winie lub niewinności oskarżonego. Nowe orzeczenie ogłaszano na rozprawie, które doręczano było jedynie na wyraźne żądanie obwinionego. Postępowanie zwyczajne od nakazowego różniło się tym, że w tym pierwszym należało wyznaczyć rozprawę i wezwać obwinionego do osobistego stawiennictwa lub zobowiązać go do nadesłania na piśmie wyjaśnień. Dodatkowo w postępowaniu tym możliwe było nałożenie maksymalnych zarówno kar grzywien, jak i aresztu. Postępowanie nakazowe było postępowaniem fakultatywnym, to znaczy że organ władzy mógł od razu wyznaczyć postępowanie zwyczajne i rozprawę z udziałem stron.

Od kary wymierzonej w trybie zwyczajnego postępowania karnoadministracyjnego stronie przysługiwało prawo zaskarżenia sprawy do sądu powszechnego $\mathrm{w}$ terminie 7 dni od daty ogłoszenia orzeczenia. Wniesienie żądania skierowania spawy na drogę postępowania 
karnego wstrzymywało wykonanie kary. Właściwym sądem był tutaj sąd okręgowy, w okręgu którego znajdowała się siedziba władzy administracyjnej wymierzającej karę. Sąd orzekał w trybie normalnego postępowania karnego, gdyż nie był związany wymiarem kary. Od orzeczenia sądu stronie przysługiwała jedynie kasacja do Sądu Najwyższego (art. 649 kodeksu postępowania karnego).

Kara grzywny do 1000 zł określała de facto górną granicę tej kary. Tym samym organ władzy administracyjnej uprawiony był do jej stopniowania w zależności od rodzaju i wagi wykroczenia. Dolną granicą kary grzywny był 1 zł.

Przewidziana przepisem art. 126 prawa przemysłowego kara aresztu do 14 dni, podobnie jak w przypadku kary grzywny, podlegała stopniowaniu. Dolna granicą areszty był areszt jednodniowy.

Sankcję cofnięcia koncesji wprowadzono do przepisów prawa przemysłowego dopiero w roku 1934. Zasadniczo miała ona charakter porządkowy, dyscyplinujący, czasowy, a to z uwagi na jej orzekanie dopiero w sytuacji, gdy przemysłowiec w ciagu ostatnich 3 lat został trzykrotnie prawomocnie ukarany karą grzywny lub aresztu, a nadal naruszał przepisy prawa przemysłowego $\mathrm{w}$ zakresie prowadzonym przez siebie przemyśle koncesjonowanym.

\section{ZAKOŃCZENIE}

Kończąc, chciałbym poruszyć kwestię obowiązywania przepisów prawa przemysłowego w nowych warunkach politycznych i gospodarczych zaistniałych w Polsce po roku 1944. Jest to o tyle ciekawe, że jego przepisy nie zostały uznane za sprzeczne z zasadami ówczesnego ustroju prawno politycznego, stając się instrumentem rugowania prywatnej działalności gospodarczej na rzecz tak zwanej gospodarki uspołecznionej. Miało to miejsce zwłaszcza po ogłoszeniu „bitwy o handel". Ograniczono wówczas listę działań wolnych i wprzęgnięto prawo przemysłowe w rygory gospodarki planowej, w której działalność podmiotów prywatnych była marginalna. Wskazuje to jednoznacznie, że regulacje prawa przemysłowego zawierające funda- 
mentalną zasadę wolności przemysłowej były odpowiednie dla dwóch różnych modeli ustroju prawno politycznego i gospodarczego.

Ostateczny byt prawny prawo przemysłowe zakończyło na mocy przepisu art. 45 ustawy o wykonywaniu i organizacji rzemiosła z dnia 8 czerwca 1972 roku $^{36}$. Co ciekawe, do roku 1972 funkcjonował przepis art. 3, stanowiący o wolności wykonywania i prowadzenia działalności przemysłowej (gospodarczej). Był to jednak fikcyjny zapis, który stracił swą moc z uwagi na wejście w życie wielu tak zwanych. aktów powiązanych, które wypaczyły jego podstawowe znaczenie.

Polish Industrial Law 1927-1939

\section{Summary}

Mutual relations between the state and industry have changed substantially in the early twentieth century. Formed the major national ompanies which have obtained legal protection acquired economic position. A manifestation of protective measures was the introduction of the concession to operate certain industrial activities. Duty concession staggered principle of freedom of industry and introduced the principle of regulation (licensing).

For the period above accounted for the first codification of Polish coherent industrial such as regulation of the Polish President on 7 June 1927, industrial law, with effect from 16 December 1927, modeled primarily on the Austrian and German law on industrial property. The Act contains no provisions industry standard for the period of capitalism the first quarter of the twentieth century, and is due to the contemporary system of economic relations, which gave her more than once on the archaic nature of some regulation.

In addition to the undoubted success of the enactment of uniform laws for the whole country was to move the industry with its provisions explicitly the principle of art. March 101 of the Constitution places the freedom to choose classes and earn money. A reflection of this was the provision of

${ }^{36}$ Dz.U. Nr 23, poz. 164. 
Article. 3 industrial law, under which the industry was to conduct free and allowed anyone, unless the provisions of industrial law did not provide that the exception or limitation.

Statutory definition of industry modeled on the achievements of the jurisprudence of the German industrial law, defined it as any employment or business carried out by itself, a commercial and professional use, no matter whether it was the activities of producing, processing, trade, or services.

The Act divided the industry into two basic categories: a permanent base - industry-free, fully licensed and crafts as well as no permanent residence (circular). Sometimes a third category of industries considered to run the industry at the fair.

Launch of free industry, with permanent residence, which was not subject to duty concession notice required an industrial power of the first instance. Industrial authority without undue delay seemed receipts stating the order number, under which he was entered in the register of industrial powers. The registration obligation imposed on both individuals and legal persons.

Licensed industry was industry, with permanent residence, whose launch was dependent on receipt of the concession. Industrial Law provided a long list of licensed industries, while accepting the principle that only those types of industry should be forced to obtain licenses, that are thus due to the important public interest and national security had to be made subject to strict conditions.

Craft was the peculiar kind of industry, with permanent residence, which could be performed only way to craft.

Industry without a permanent seat was called industry is defined as a circular gainful employment, self-made, professionally and personally without a permanent seat in the industrial field, for example, selling goods in other places other than goods intended for sale. The person who wanted to lead the industry circular was required to obtain a license, which has provided industrial power of the first instance in the form of an administrative decision. It was not possible to start and perform circular industry before obtaining a license. 
One of the major forms of trade in the interwar period was the sale takes place at the fair. The activities fair was regulated in the law industry as a special type of industry and subject to strict legal restrictions. The basic condition of business was to obtain a fair municipality's powers to conduct fair markets (the property or place) and keeping it in the days and hours established in the regulations.

In terms of industrial law in the new political and economic conditions have occurred in Poland after 1944. It is very interesting that its provisions were not considered to be contrary to the principles of contemporary legal and political system, becoming the instrument of delivery volume of private economic activity for the so-called national economy. Therefore, the provisions of the Regulation in force until 1972. 